\title{
KARAKTERISTIK DAN AKTIVITAS ANTIOKSIDAN SABUN PADAT DENGAN PENAMBAHAN EKSTRAK KULIT BUAH NAGA (Hylocereus polyrizhus)
}

\author{
Moch. Purwanto ${ }^{1 *}$, Elly Septia Yulianti ${ }^{1}$, Ine Nisrina Nurfauzi ${ }^{1}$, Winarni ${ }^{2}$ \\ ${ }^{1}$ Program Studi Teknik Kimia, Institut Teknologi Kalimantan, Jalan Soekarno-Hatta km. 15 Karang Joang, \\ Balikpapan, 76127, Indonesia \\ ${ }^{2}$ Program Studi Matematika, Institut Teknologi Kalimantan, Jalan Soekarno-Hatta km. 15 Karang Joang, \\ Balikpapan, 76127, Indonesia
}

\begin{abstract}
Author Utama*, email: m.purwanto@itk.ac.id
Co-author, email: $05151012 @$ student.itk.ac.id

Co-author, email: 05151018@student.itk.ac.id

Co-author, email: winarni@itk.ac.id
\end{abstract}

\begin{abstract}
The extract of dragon fruit peels containing a lot of antioxidants which can inhibit free radicals. The addition of extract into solid soap can increase the activity of antioxidant. This research aims to know the effects of extract composition on the solid soap properties (i.e. $\mathrm{pH}$ and antioxidant activity). The extract composition and reaction time were varied at 1 to $1.5 \mathrm{wt} \%$ and 20 to 40 minutes, respectively. The extract was obtained by maceration method followed by evaporation process, in order to remove the ethanol (EtOH) remains. The solid soap is made by reacting Virgin Coconut Oil (VCO) with sodium hydroxide (NaOH) and several additives. Solid soap is processed by the hot process saponification method. The result showed that the prepared solid soaps contain a $\mathrm{pH} 8.29$ - 10 and the antioxidant activity in inhibition concentration $\left(I C_{50}\right)$ with value 215.27 - 1671.33 ppm. It indicates that solid soap with saponification time 20 minutes with 1.5 wt\% extract has the best result according to SNI 3532:2016.
\end{abstract}

Keywords: Solid soap; extract; dragon fruit; antioxidant

\section{ABSTRAK}

Ekstrak kulit buah naga mengandung banyak antioksidan yang dapat menghambat radikal bebas. Penambahan ekstrak ke dalam sabun padat dapat meningkatkan aktivitas antioksidan. Penelitian ini bertujuan untuk mengetahui pengaruh komposisi ekstrak terhadap sifat sabun padat ( $\mathrm{pH}$ dan aktivitas antioksidan). Komposisi ekstrak dan waktu reaksi bervariasi pada 1 sampai 1,5\% berat dan 20 hingga 40 menit, masingmasing. Ekstrak diperoleh dengan metode maserasi diikuti dengan proses penguapan, untuk menghilangkan etanol (EtOH) yang tersisa. Sabun padat dibuat dengan mereaksikan Virgin Coconut Oil (VCO) dengan natrium hidroksida $(\mathrm{NaOH})$ dan beberapa aditif. Sabun padat diproses dengan metode saponifikasi proses panas. Hasil penelitian menunjukkan bahwa sabun padat mengandung pH 8,29 - 10 dan aktivitas antioksidan dalam konsentrasi penghambatan (IC50) dengan nilai 215,27 - 1671,33 ppm. Ini menunjukkan bahwa sabun padat dengan waktu saponifikasi 20 menit dengan ekstrak 1,5\% berat memiliki hasil terbaik sesuai dengan SNI 3532: 2016.

Kata Kunci: Sabun padat; ekstrak; buah naga; antioksidan

\section{PENDAHULUAN}

Sabun padat merupakan produk turunan minyak hasil pencampuran natrium atau kalium dengan asam lemak. Secara umum, sabun berbentuk padat atau cair, memiliki busa dan aroma yang bervariasi[8]. Sabun diperoleh dari reaksi saponifikasi antara asam lemak dan basa sehingga menghasilkan sabun dan gliserol. Sabun merupakan molekul surfaktan yang memiliki bagian hidrofilik (gugus COONa) dan hidrofobik 
(gugus R) [2]. Saat ini terdapat 3 jenis sabun padat diantaranya opaque, translucent, dan transparan. Sabun transparan banyak diminati karena tampilannya yang menarik dan berkilau serta memungkinkan dijadikan sabun herbal karena kandungannya aman untuk kulit dan dapat divariasikan dengan aditif herbal lainnya [3].

Radikal bebas merupakan salah satu bentuk senyawa oksigen reaktif yang memiliki elektron tidak berpasangan sehingga cenderung tidak stabil. Elektron yang tidak berpasangan ini akan berusaha mengikat electron lain agar menjadi stabil. Antioksidan merupakan senyawa fitokimia yang berperan sebagai pendonor electron kepada radikal bebas yang bersifat oksidan. Antioksidan digunakan sebagai pencegah terjadinya proses oksidasi yang menyebabkan kerusakan dan ketengikan serta kerusakan fisik lainnya. Efek radikal bebas pada tubuh dapat menyebabkan kerusakan fungsi sel-sel tubuh yang menjadi penyebab timbulnya penyakit degeneratif. Tubuh manusia secara alami memproduksi antioksidan berupa sel imun dalam jumlah terbatas. Untuk memenuhi kebutuhan antioksidan tersebut, diperlukan antioksidan eksternal yang dapat diperoleh dari sayur dan buah. Contoh antioksidan yang sangat berpengaruh terhadap sistem imun tubuh adalah vitamin $\mathrm{C}$, vitamin $\mathrm{E}, \mathrm{Se}, \mathrm{Zn}$, dan glutation [4].

Buah naga atau Hyocereus polirizhus merupakan tumbuhan seperti kaktus yang tubuh di daerah tropis maupun subtropics sehingga pertumbuhannya tidak tergantung pada musim [5]. Buah naga dipilih karena memiliki kadar antioksidan yang paling tinggi diantara beberapa buah-buahan lain yang tumbuh di wilayah Balikpapan. Kulit buah naga memiliki kandungan antioksidan dengan nilai inhibition concentration $\left(\mathrm{IC}_{50}\right)$ sebesar $31.4 \mathrm{mg} / \mathrm{L}$. [6].

\section{METODE PENELITIAN}

\section{Material}

Bahan-bahan yang digunakan pada penelitian ini adalah kulit buah naga merah yang diperoleh dari Perkebunan Buah Naga Kelurahan Karang Joang KM 24 Balikpapan Utara, etanol $70 \%$, virgin coconut oil (VCO), larutan sodium hidroksidan $(\mathrm{NaOH}) 30 \%$, butyl hidroksitoluen (BHT), asam stearate, propilen glikol (PG), trietanolamin (TEA), gliserin, etilendiamin tetraamida (EDTA), gula, air dan Kristal 1,1-difenil-2-pikrilhidrazil (DPPH).

\section{Instrumentasi}

Alat-alat yang digunakan ppada penelitian ini adalah alat-alat gelas (Pyrex), blender (Miyako), magnetic stirrer bar, pompa vacuum $V-700$, rotary vacuum evaporator (Buchi Rotavapor R11), hotplate stirrer (Thermo Fisher Scientific), neraca analitik (Ohauss), tabung reaksi (Pyrex), spektrofotometer UV-Vis (Thermo Scientific), penetrometer (ASM D-5), $\mathrm{pH}$ meter (Risantec).

\section{Prosedur}

\section{Ekstraksi Kulit Buah Naga}

Buah naga dari Jalan Soekarno Hatta km. 24 dipisahkan antara kulit dan buahnya. Setelah dibersihkan, kulit buah naga dipotong kecil dan dikeringkan menggunakan oven dengan suhu $55^{\circ} \mathrm{C}$ selama 24 jam. Kulit buah naga kering dihancurkan menggunakan 
blender sampai halus. Kemudian dilakukan proses maserasi menggunakan etanol $70 \%$ dengan rasio padatan dan pelarut sebesar 1:10. Maserasi dilakukan selama 3 hari tanpa dilakukan pergantian pelarut. Hasil maserasi disaring untuk memisahkan filtrat dan residu serbuk kulit buah naga. Filtrat akan dievaporasi untuk memisahkan ekstrak kental dengan pelarut etanol dengan suhu $55^{\circ} \mathrm{C}$ pada tekanan vakum.

\section{Proses Pembuatan Sabun Padat}

Pembuatan sediaan sabun padat pada penelitian ini menggunakan formulasi Cognis (2003) yang telah dimodifikasi [7].

Tabel 1. Formulasi sabun padat dengan penambahan ekstrak kulit buah naga (Hylocereus polyrhizus)

\begin{tabular}{cc}
\hline Bahan & $\begin{array}{c}\text { Perbandingan } \\
(\% \mathbf{b} / \mathbf{b})\end{array}$ \\
\hline VCO & 45.41 \\
Asam stearat & 5.16 \\
BHT & 0.1 \\
Gliserin & 2.06 \\
EDTA & 0.1 \\
PG & 10.32 \\
TEA & 2.06 \\
Gula & 8.26 \\
NaOH 30\% & 22.39 \\
Air & 4.13
\end{tabular}

Adapun tahap awal pembuatan sabun pada penelitian ini adalah melarutkan BHT, VCO, dan asam stearate sampai homogen dengan pemanasan $60^{\circ} \mathrm{C}$ dengan laju pengadukan $250 \mathrm{rpm}$. Kemudian ditambahkan $\mathrm{NaOH} 30 \%$ sehingga terjadi proses saponifikasi sampai terbentuk massa kental. Setelah itu campuran gliserin, PG, EDTA, dan TEA ditambahkan kedalam campuran massa sabun dan diaduk sapai homogeny pada suhu $60^{\circ} \mathrm{C}$. Kemudian campuran gula dan air yang telah homogeny ditambahkan kedalam campuran sabun. Proses pengadukan dilakukan dengan variasi waktu reaksi 20, 30 dan 40 menit. Setelah itu ditambahkan sejumlah ekstrak dengan variasi $0 ; 1 ; 1.25$; dan $1.5 \%$.

\section{HASIL DAN PEMBAHASAN}

\section{Analisis Organoleptik}

Uji organoleptik pada penelitian ini dilakukan untuk mengetahui penerimaan konsumen terhadap sabun padat yang dihasilkan, yaitu berupa warna, aroma dan tingkat kekerasan sabun oleh 20 panelis.

Untuk menentukan produk yang paling disukai, perhitungan dilakukan dengan cara menjumlahkan nilai dari presentase panelis yang menyatakan suka (4) dan sangat suka (5) pada kuesioner yang telah disediakan. Kedua nilai tertinggi tersebut dinyatakan sebagai presentase kesukaan panelis pada produk sabun padat dengan penambahan ekstrak kulit buah naga. Dari data kuesioner yang diterima, didapatkan hasil tingkat kesukaan panelis terhadap warna, aroma, dan tingkat kekerasan pada Table 2.

Berdasarkan hasil pengamatan, perbedaan warna pada setiap sabun antar perlakuan tidak terlalu signifikan karena perbedaan panambahan ekstrak kulit buah naga yang digunakan pada setiap perlakuan tidak terlalu besar. Produk tanpa penambahan ekstrak kulit buah naga akan berwarna putih susu. Ekstrak kulit buah naga murni pada dasarnya berwarna merah tua kecoklatan, sehingga sediaan sabun padat 
dengan penambahan ekstrak kulit buah naga yang dihasilkan akan berwarna kuning tua hingga coklat tua. Oleh karena itu, semakin banyak penambahan ekstrak kulit buah naga maka warna yang akan dihasilkan akan semakin coklat atau gelap.

Tabel 2. Hasil organoleptic sabun padat dengan penambahan ekstrak kulit buah naga terhadap warna, aroma dan tingkat kekerasan sabun.

\begin{tabular}{ccccc}
\hline \multicolumn{3}{c}{ Perlakuan } & \multicolumn{3}{c}{$\begin{array}{c}\text { Tingkat Kesukaan (\%) } \\
\text { Parameter Suka + Sangat } \\
\text { Suka }\end{array}$} \\
\hline Waktu & $\begin{array}{c}\text { Ekstrak } \\
(\%)\end{array}$ & Warna & Aroma & Kekerasan \\
\hline \multirow{3}{*}{20} & 0 & 80 & 55 & 50 \\
& 1 & 10 & 5 & 25 \\
& 1.25 & 10 & 5 & 40 \\
& 1.5 & 10 & 5 & 50 \\
\hline \multirow{3}{*}{30} & 0 & 85 & 45 & 75 \\
& 1 & 15 & 10 & 55 \\
& 1.25 & 10 & 5 & 15 \\
& 1.5 & 75 & 0 & 40 \\
40 & 0 & 70 & 45 & 65 \\
& 1 & 10 & 10 & 35 \\
& 1.25 & 10 & 0 & 15 \\
& 1.5 & 15 & 0 & 5 \\
\hline
\end{tabular}

Hasil uji organoleptik sabun padat dengan penambahan ekstrak kulit buah naga terhadap aroma pada tingkat suka dan sangat suka yang paling tinggi adalah pada variabel waktu pengadukan 20 menit dengan penambahan ekstrak $0 \%$ dengan presentasi penilaian $55 \%$. Pada kondisi ini, para panelis ternyata lebih menyukai sabun padat dengan aroma fragrances oil yang lebih kuat. Hal ini menunjukkan bahwa semakin tinggi penambahan ekstrak kulit buah naga maka aroma pewangi yang ditambahkan pada formulasi sediaan sabun yang dihasilkan akan semakin lemah.

Tingkat kesukaan panelis untuk kekerasan paling tinggi adalah pada variabel waktu pengadukan 30 menit dan penambahan ekstrak $0 \%$ dengan persentase penilaian $75 \%$. Para panelis lebih menyukai sabun dengan kekerasan yang tinggi, dimana kekerasan sabun dipengaruhi oleh jumlah ekstrak yang ditambahkan kedalam formula sabun.

\section{Analisis pH}

Berdasarkan hasil analisis, diperoleh nilai $\mathrm{pH}$ sabun padat cenderung menurun seiring dengan bertambahnya konsentrasi ekstrak kulit buah naga yang digunakan. Adapun sabun padat yang diperoleh pada penelitian ini memiliki rentang $\mathrm{pH}$ antara 8.79 - 10.0. Sedangkan menurut SNI, rentang $\mathrm{pH}$ sabun padat berkisar antara $9-11$. Sengga sabun padat yang diperoleh pada penelitian ini pada beberapa variabel masih memiliki kekurangan untuk memenuhi standar SNI. Hal ini diduga karena penambahan ekstrak kulit buah naga yang mengandung senyawa alkaloid yang bersifat basa pada sediaan sabun padat yang mempengaruhi nilai derajat keasaman $(\mathrm{pH})$ yang dihasilkan.

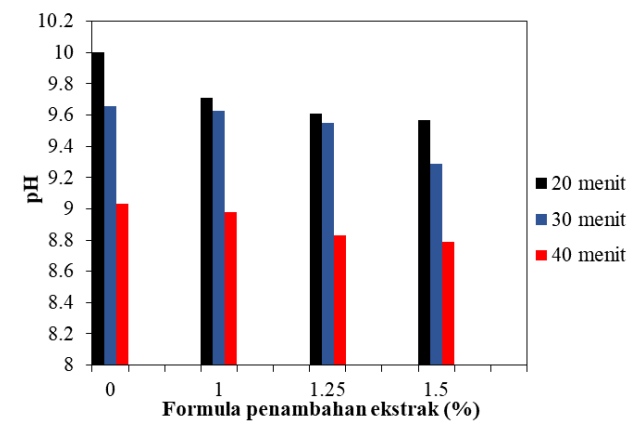

Gambar 1. Perbandingan hasil pH sabun untuk tiap formula dan tiap waktu pengadukan 
Selain itu, dari Gambar 1 dapat dilihat adanya pengaruh waktu pengadukan terhadap $\mathrm{pH}$ sabun padat yang dihasilkan. Dengan semakin bertambahnya waktu pengadukan dapat menyebabkan turunnya pH sabun yang dihasilkan. Hal ini disebabkan oleh semakin lama waktu pengadukan menyebabkan waktu interaksi antara minyak dan alkali semakin besar, maka reaksi akan mendekati kesetimbangan sehingga residu alkali akan semakin rendah yang mana akan menyebabkan produk sabun padat tidak terlalu basa [8].

\section{Analisis Aktivitas Antioksdan}

Penelitian ini menggunakan DPPH sebagai metode analisis untuk mengetahui aktivitas antioksidan dari sediaan sabun yang ditambahkan ekstrak kulit buah naga. Proses pengujian ini dilaksanakan di Laboratorium Farmokologi Fakultas Kedokteran Universitas Mulawarman Samarinda. Metode analisis aktivitas antioksidan menggunakan DPPH merupakan salah satu metode uji kuantitatif untuk mengetahui seberapa besar aktivitas ekstrak kulit buah naga merah (Hylocereus polyrhizus) sebagai antioksidan. Menurut Pourmorad dkk (2006), metode pengujian menggunakan DPPH merupakan metode konvensional dengan pengerjaan yang mudah, cepat, dan sensitif dengan pengujian menggunakan spektrofotometer.

Pengukuran aktivitas antioksidan secara spektrofotometri dilakukan pada panjang gelombang maksimum DPPH sebesar $517 \mathrm{~nm}$. Metode DPPH didasarkan pada penurunan nilai absorbansi akibat perubahan warna larutan. Reagen DPPH yang bereaksi dengan antioksidan mula-mula berwarna ungu, lalu akan berubah manjadi kuning, dimana intensitas warna yang dihasilkan sangat bergantung dari kemampuan antioksidan itu sendiri. Proses ini terjadi setelah masa inkubasi selama 30 menit. Perubahan ini terjadi saat radikal DPPH ditangkap oleh antioksidan yang melepas atom hidrogen untuk membantuk DPPH-Hidrazil yang lebih stabil [27].

Pengamatan terhadap intensitas warna pada penelitian ini dilakukan pada sediaan sabun yang telah ditambahkan ekstrak kulit buah naga dalam beberapa konsentrasi. Adapun konsentrasi sediaan sabun yang digunakan yaitu 25 ppm, 50 ppm, 100 ppm, 150 ppm, dan 200 ppm. Perbedaan konsentrasi ini bertujuan untuk mengetahui tingkat peredaman warna sabagai akibat adanya senyawa antioksidan yang mampu mengurangi intensitas warna ungu dari DPPH.

Semua data hasil pengukuran pada penelitian ini menunjukkan adanya aktivitas perendaman radikal DPPH yang dilihat dari adanya penurunan nilai absorbansi radikal DPPH. Baik aktivitas antioksidan dari ekstrak kulit buah naga murni maupun sediaan sabun yang telah ditambahkan ekstrak kulit buah naga di dalamnya. Adapun penentuan nilai aktivitas antioksidan dapat dilakukan dengan menggunakan persamaan regresi.

Persamaan regresi dari konsentrasi ekstrak kulit buah naga murni (sumbu $\mathrm{x}$ ) dengan persen (\%) inhibasi aktivitas antioksidan (sumbu y) adalah $\mathrm{y}=0.0018 \mathrm{x}+$ 0.3353 , dengan nilai koefisien korelasi 0.959 . Nilai koefisien korelasi yang bernilai positif ini menggambarkan bahwa dengan meningkatnya konsentrasi ekstrak kulit buah 
naga merah, maka akan semakin besar pula aktivitas antioksidannya. Adapun hubungan tersebut dapat terlihat pada Gambar 3.

Adapun hasil pengujian ekstrak kulit buah naga murni menunjukkan nilai $\mathrm{IC}_{50}$ sebesar $91.5 \mu \mathrm{g} / \mathrm{ml}$. Hal ini menunjukkan bahwa ekstrak kulit buah naga mengandung senyawa aktif antioksidan dengan kategori kuat.

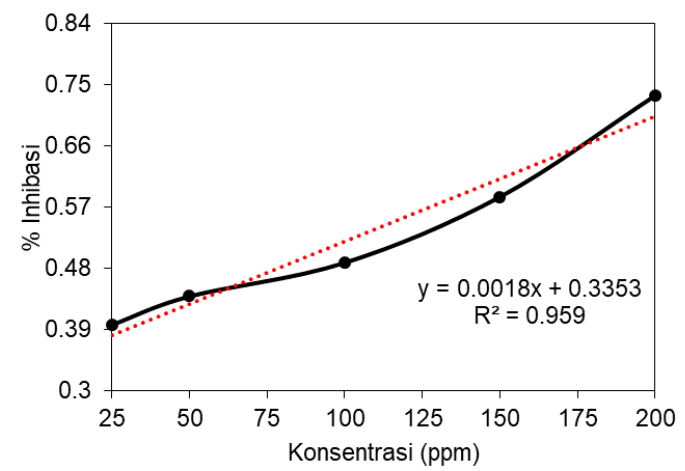

Gambar 2. Grafik penentuan nilai $I_{50}$

Senyawa yang memiliki nilai $\mathrm{IC}_{50}<50$ $\mu \mathrm{g} / \mathrm{ml}$ memiliki sifat antioksidan yang sangat kuat, nilai $\mathrm{IC}_{50} \quad 50-100 \mu \mathrm{g} / \mathrm{ml}$ termasuk kategori antioksidan kuat, nilai $\mathrm{IC}_{50} \quad 100-150$ $\mu \mathrm{g} / \mathrm{ml}$ termasuk kategori antioksidan sedang, dan nilai $I_{50} \quad 150-200 \mu \mathrm{g} / \mathrm{ml}$ termasuk kategori antioksidan lemah, sedangkan rentang nilai $\mathrm{IC}_{50} 200-1000 \mu \mathrm{g} / \mathrm{ml}$ tergolong kategori antioksidan yang sangat lemah [9] [35].

Adapun hasil pengamatan aktivitas antioksidan pada sediaan sabun dengan penambahan ekstrak kulit buah naga sapat dilihat pada Tabel 3.

Hasil pengamatan terhadap aktivitas antioksidan yang dilakukan terhadap sediaan sabun padat dengan penambahan ekstrak kulit buah naga dari semua formula juga memiliki kemampuan sebagai penangkap radikal bebas, hanya saja nilai $\mathrm{IC}_{50}$ yang dihasilkan juga tergolong kategori yang sangat lemah. Hal tersebut dibuktikan dari nilai $\mathrm{IC}_{50}$ yang dihasilkan menyatakan nilai yang lebih dari $200 \mu \mathrm{g} / \mathrm{ml}$.

Tabel 3 Nilai $I_{50}$ untuk tiap formula dan waktu

\begin{tabular}{ccc}
\multicolumn{3}{c}{ pengadukan } \\
$\begin{array}{c}\text { Waktu } \\
\begin{array}{c}\text { Pengadukan } \\
(\mathbf{m i n})\end{array}\end{array}$ & $\begin{array}{c}\text { Ekstrak } \\
(\% \mathbf{w} / \mathbf{w})\end{array}$ & $\begin{array}{c}\mathbf{I C}_{50} \\
(\boldsymbol{\mu} \mathbf{g} / \mathbf{m l})\end{array}$ \\
\hline & 0 & 1557.67 \\
20 & 1 & 988.75 \\
& 1.25 & 692.50 \\
& 1.5 & 215.27 \\
\hline 30 & 0 & 1577.67 \\
& 1 & 1095.75 \\
& 1.25 & 695.29 \\
& 1.5 & 585.50 \\
\hline \multirow{2}{*}{40} & 0 & 1671.33 \\
& 1 & 1222.25 \\
& 1.25 & 721.86 \\
& 1.5 & 629.86 \\
\hline Ekstrak Murni & - & 91.5 \\
\hline
\end{tabular}

Berdasarkan hasil skrining fitokimia, diduga golongan senyawa yang memberikan aktivitas antioksidan terbesar dalam ekstrak kulit buah naga adalah flavonoid. Senyawa flavonoid berperan sebagai antioksidan karena memiliki gugus hidroksil yang dapat melepaskan proton dalam bentuk ion hidrogen. Ion hidrogen hanya memiliki satu buah proton dan tidak memiliki elektron, sehingga dalam elektron radikal yang terdapat pada atom nitrogen pada senyawa DPPH berikatan dengan ion hidrogen dan menghasilkan DPPH yang tereduksi [9]. 
Namun, paparan panas yang berlebihan pada ekstrak kulit buah naga yang ditambahkan ke dalam sabun padat pada saat proses saponifikasi menjadikan senyawa flavonoid menjadi tidak stabil.

Selain itu, flavonoid yang terkandung dalam sediaan sabun dengan tambahan ekstrak kulit buah naga yang telah tercampur oleh berbagai senyawa yang bersifat nonpolar pada saat pembuatannya terutama vCO (Virgine Coconut Oif). Hal ini menyebabkan flavonoid yang terkandung oleh ekstrak kulit buah naga masih terikat pada gugus glikosidanya sehingga menghambat pengikatan radikal DPPH dan mengakibatkan lemahnya aktivitas antioksidan yang dihasilkan. Hal tersebut mengakibatkan flavonoid tidak dapat mendonasikan hidrogen untuk menangkal radikal bebas karena terjadinya halangan sterik. Adanya gugus lain di dalam kandungan ekstrak kulit buah naga juga dapat menyebabkan flavonoid tereliminasi [9].

Lemahnya kandungan antioksidan yang terkandung dalam sediaan sabun ini juga disebabkan oleh konsentrasi ekstrak kulit buah naga yang ditambahkan memiliki konsentrasi yang sangat kecil dibandingkan dengan jumlah berat bersih sediaan sabun. Konsentrasi ekstrak kulit buah naga yang ditambahkan dalam sediaan sabun berjumlah 1, 1.25, dan $1.5(\% \mathrm{w} / \mathrm{w})$. Sehingga daya absorbansi yang dihasilkan menjadi semakin besar untuk menangkal radikal bebas DPPH.

Selain itu, dalam penelitian ini juga membandingkan beberapa hasil aktivitas antioksidan dalam sediaan sabun padat dalam konsentrasi dan waktu pengadukan yang berbeda. Menurut hasil yang disajikan pada Tabel 3, hasil aktivitas antioksidan tertinggi dihasilkan oleh sabun padat dengan konsentrasi ekstrak sebesar $1.5(\% \mathrm{w} / \mathrm{w})$ pada pengadukan 20 menit. Nilai $I_{50}$ yang dihasilkan pada kondisi ini sebesar 215.27 $\mu \mathrm{g} / \mathrm{ml}$. Jumlah tersebut bahkan jauh lebih rendah dibandingkan dengan hasil pengujian $I_{50}$ pada sampel ekstrak kulit buah naga murni. Hal ini dapat disebabkan oleh adanya penambahan BHT (Butil Hidroksitoluen) yang merupakan antioksidan sintetik. Pada dasarnya, penggunaan BHT pada formulasi sabun padat ini difungsikan untuk menjaga minyak dalam sabun tidak teroksidasi yang mana akan menyebabkan ketengikan.

Tampak dari Gambar 4, hasil yang diperoleh menunjukkan bahwa semakin meningkat ekstrak kulit buah naga yang digunakan pada formulasi sabun padat, maka semakin kuat pula aktivitas antioksidan yang akan dihasilkan. Akan tetapi pada kondisi ini, tidak hanya jumlah konsentrasi saja yang memperngaruhi jumlah aktivitas antioksidan dalam sediaan sabun padat, melainkan waktu pengadukan pada saat proses saponifikasi juga sangat berpengaruh pada aktivitas antioksidan yang dihasilkan.

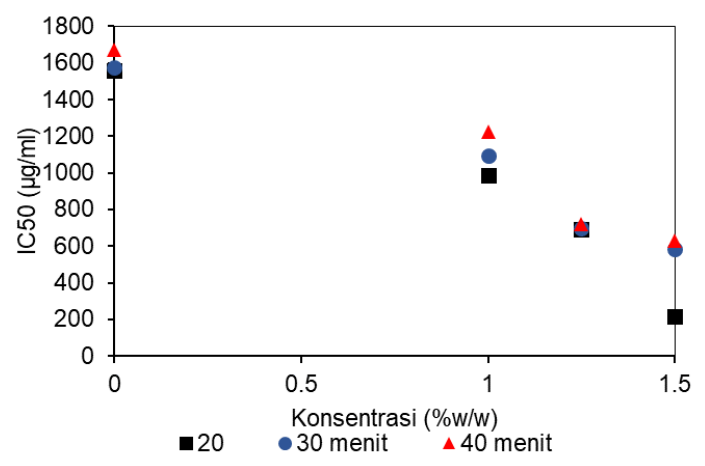

Gambar 3. Perbandingan nilai $I C_{50}$ untuk tiap formula dan waktu pengadukan 
Pengaruh waktu pengadukan terhadap aktivitas antioksidan dapat diamati melalui sediaan sabun padat dari formulasi blangko. Kandungan antioksidan yang terdapat pada formulasi blangko ini disebabkan oleh adanya penambahan BHT (Butil Hidroksitoluen). BHT merupakan antioksidan sintetik yang pada dasarnya berfungsi untuk menjaga agar minyak dalam sabun tidak teroksidasi yang akan menyebabkan ketengikan. Pada hasil penelitian ini didapatkan bahwa nilai $\mathrm{IC}_{50}$ formulasi blangko yang dihasilkan akan semakin besar dengan bertambahnya waktu pengadukan yang digunakan.

Pengadukan pada proses saponifikasi ini bertujuan untuk memperbesar probobalitas interaksi antar molekul-molekul reaktan yang bereaksi. Jika interaksi antar molekul reaktan semakin besar, maka kemungkinan terjadinya reaksi semakin besar pula. Hal ini sesuai dengan persamaan Arhenius dimana konstanta kecepatan reaksi k akan semakin besar dengan semakin sering terjadinya interaksi. Sedangkan semakin lama waktu reaksi saponifikasi berlangsung, dapat menyebabkan banyak minyak yang dapat tersabunkan. Akan tetapi, jika reaksi telah mencapai kondisi setimbangnya, penambahan waktu tidak akan meningkatkan jumlah minyak yang tersabunkan [38].

Dari hasil penelitian yang diperoleh, kondisi terbaik sabun yang dihasilkan terjadi pada waktu pengadukan selama 20 menit. Ternyata semakin lama waktu pengadukan pada proses saponifikasi, maka aktivitas antioksidan sabun padat akan semakin kecil karena nilai $I_{50}$ yang akan dihasilkan akan semakin besar. Hal ini disebabkan oleh pengaruh suhu pada proses saponifikasi.
Penelitian ini menggunakan suhu konstan pada semua proses saponifikasi sebesar $60^{\circ} \mathrm{C}$. Ekstrak kulit buah naga yang ditambahkan ke dalam formulasi sabun pada proses saponifikasi selama 40 menit akan berkontak dengan suhu panas yang lebih lama dibandingkan pada proses saponifikasi selama 20 menit. Hal ini mengakibatkan ekstrak kulit buah naga akan mulai rusak oleh paparan suhu tinggi dalam waktu yang lama. Sehingga kondisi inilah yang mengakibatkan kinerja antioksidan akan semakin melemah.

\section{KESIMPULAN}

Kesimpulan yang diperoleh dari penelitian ini adalah:

1. Karakteristik sabun padat yang dihasilkan dengan penambahan ekstrak kulit buah naga akan berpengaruh pada warna dan kekerasan sabun. Semakin lama waktu pengadukan, maka warna sabun akan semakin gelap dan akan semakin keras.

2. Derajat keasaman $(\mathrm{pH})$ sabun padat dipengaruhi oleh waktu pengadukan, dimana semakin lama waktu pengadukan maka $\mathrm{pH}$ sabun akan semakin kecil dengan rentang $\mathrm{pH}$ untuk semua sabun antara 8.29-10.

3. Sabun padat yang dihasilkan memiliki aktivitas antioksidan dan hasil antioksidan yang terbaik ditunjukkan oleh sabun padat dengan waktu pengadukan 20 menit dan penambahan ekstrak 1.5\%. Aktivitas antioksidan dinyatakan dalam nilai inhibition concentration atau $\mathrm{IC}_{50}$ yaitu sebesar $215.27 \mathrm{ppm}$

\section{DAFTAR PUSTAKA}

[1] Agustini, N. W. S., Winarni, A. H., "Karakteristik dan Aktivitas Antioksidan Sabun Padat Transparan 
yang Diperkaya dengan Ekstrak Kasar Karotenoid Chlorella pyrenoidosa", JPB Kelautan dan Perikanan, 12(1), pp.1-12, 2017.

[2] Anggraini, T., Ismanto, S. D., Dahlia., "The Making of Transparent Soap from Green Tea Extract", International Journal on Advanced Science Engineering Information Technology, 5(1), pp.349356, 2015.

[3] Barel, A. O., Paye, M., Maibach, H. I., Handbook of Cosmetic Science and Technology, New York, Marcel Dekker Inc, 2001.

[4] Bewer, M. S., "Comprehensive review in food science and food safety", Institute of Food Technologists, Chicago, America, 2011.

[5] Bidilah, S. A., Rumape, O., Mohamad, E., "Optimasi Waktu Pengadukan dan Volume $\mathrm{KOH}$ Sabun Cair Berbahan Dasar Minyak Jelantah", Jurnal Entropi, 12(1), pp.55-60, 2017.

[6] (2014) BPS (Badan Pusat Statistika). [Online]. Available: www.bps.go.id

[7] Brand-Williams, W., Cubelier, M. E., Berset, C. "Use of a free radical method to evaluate antioxidant activity", LWT-Food Science and Technology, 28(1), pp.25-30, 1995.

[8] Standar Nasional Indonesia : Sabun Mandi Padat, BSN (Badan Standarisasi Nasional), 2016.

[9] Budilaksono, W., Wahdaningsih, S., Fahrurroji, A., "Uji Aktivitas Antioksidan Fraksi N-Heksana Kulit Buah Naga Merah (Hylocereus lemairei Britton dan Rose) Menggunakan Metode DPPH (1,1-Difenil-2Pikrilhidrazil)", Universitas Tanjungpura, Pontianak, Indonesia, 2011.

[10] Bustan, M. D., Febriyani, R., Pakpahan, H. "Pengaruh Waktu Ekstraksi dan Ukuran Partikel Terhadap Berat Oleoresin Jahe yang Diperoleh dalam Berbagai Jumlah Pelarut Organik (Methanol)", Jurnal Teknik Kimia, 15(1), 16-26, 2008.

[11] Cosmetic Toiletry., Fragrance Association., Guidelines on Stability Testing of Cosmetic Product. Washington DC, United States:CTFA, 2004.

[12] Fathurrachman, D. A., Pengaruh Konsentrasi Pelarut Terhadap Aktivitas Antioksidan Ekstrak Etanol Daun Sirsak (Annona muricata Linn) dengan Metode Peredaman Radikal Bebas DPPH, Skripsi, UIN Syafid Hidayatullah, Jakarta, 2014

[13] Fitrianingsih, S. P., Lestasi, F., Aminah, S., "Uji Efek Antioksidan Etanol Kulit Buah Salak (Salacca zalacca (Gaertner) Voss) dengan Metode Peredaman DPPH", Prosiding Seminar Nasional Penelitian dan PKM Sains, Teknologi, dan Kesehatan, Universitas Islam Bandung, Bandung, 2014.

[14] Green, G. A., "Review: Antioxidant supplements do not reduce all-cause mortality in primary or secondary prevention", Evidence-Based Medicine, 13 (1), pp.117, 2008.

[15] Handayani, P. A., Rahmawati, A., "Pemanfaatan Kulit Buah Naga (Dragon Fruit) Sebagai Pewarna Alami Makanan Pengganti Pewarna Sintetis", Jurnal Bahan Alam Terbarukan, 1(1), pp.19-24, 2012.

[16] Hasibuan, R., Adventi, F., Rtg, R. P., "Pengaruh Suhu Reaksi, Kecepatan Pengadukan dan Waktu Reaksi pada Pembuatan Sabun Padat dari Minyak Kelapa (Coco nucifera L.)", Jurnal Teknik Kimia USU, 8(1), pp.11-17. 2019.

[17] Hatam, S. F., Suryanto, E., Abidjulu, J., "Aktivitas Antioksidan dari Ekstrak Kulit Nanas (Ananas comosus (L.) Merr)", Pharmacon Jurnal Ilmiah Farmasi, 2(1), pp.8-11, 2013.

[18] Hendradi, E., Chasanah, U., Indriani, T., "Pengaruh
Gliserin dan Propilenglikol Terhadap Karakteristik Fisik, Kimia dan SPF Sediaan Krim Tipe O/W Ekstrak Biji Kakao (Theobroma cacao L.) (Kadar Ekstrak Kakao 10\%, 15\% dan 20\%)", Jurnal Pharma Scientia, 2(1), pp.3, 2013.

[19] Hernani, Bunasor, T. K., Fitriati., "Formula Sabun Transparan Antijamur dengan Bahan Aktif Ekstrak Lengkuas (Alpinia galanga L. Swartz.)", Buletin Penelitian Tanaman Rempah dan Obat, pp.192205, 2010.

[20] Jami'ah, S. R., Ifaya, M., Pusmarani, J., “Uji Aktivitas Antioksidan Ekstrak Metanol Kulit Pisang Raja (Musa Paradisiaca sapientum) dengan Metode DPPH (2,2-Difenil-1-Pikrilhidrazil)", Jurnal Mandala Pharmacom Indonesia, 4(1), pp.33-38, 2018.

[21] Jannah, B., Sifat Fisik Sabun Transparan dengan Penambahan Madu pada Konsentrasi yang Berbeda, Skripsi, Institut Pertanian Bogor, Bogor, 2009.

[22] Kim, H. J., Choi, H. K., Moon, J. Y., "Comparative Antioxidant and Antiprolifeative Activities of Red and White Pitayas and Their Correlation with Flavonoid and Polyphenol Content", Journal of Food and Science, 76 (1), pp.C38-C45, 2010.

[23] Kristanto, D., Buah Naga: Pembudidayaan di Pot dan Kebun, Jakarta, Indonesia, Penebar Swadaya, 2008.

[24] Liaotrakoon, W., Characterization of Dragon Fruit (Hylocereus spp.) Components with Valorization Potential, PhD thesis, Belgium, 2013.

[25] Mailandari, M., Uji Aktivitas Antioksidan Ekstrak Daun Garcinia kydia Roxb. dengan Metode DPPH dan Identifikasi Senyawa Kimia Fraksi yang Aktif, Skripsi, Universitas Indonesia, Depok, 2012.

[26] Nadia, S., Riyanti., Nirmala, R., "Uji Aktivitas Antioksidan Kombinasi dari Kulit Buah Naga (Hylocereus costaricensis) dan Bunga Rosela (Hibiscus sabdariffa) dengan Metode DPPH (1,1Diphenyl-picrylhydrazyl) Beserta Bentuk Tunggalnya", Jurnal KesMaDaSka, 1(1), pp.94-99, 2016.

[27] Niah, R., Helda., "Aktivitas Antioksidan Ekstrak Etanol Kulit Buah Naga Merah Daerah Pelaihari, Kalimantan Selatan dengan Metode DPPH (2,2difenil-1-pikrilhidrazil)", Jurnal Pharmascience, 3(1), pp.36-42, 2016.

[28] Nurhadi, S. C., Pembuatan Sabun Mandi Gel Alami dengan Bahan Aktif Mikroalga Chlorrea Pyrenoidosa Beyerinck dan Minyak Atsiri Labandula Lativolia Chaix, Skripsi, Universitas Ma Chung, Malang, 2012.

[29] Nurliyana, R., Syed, Z. I., Mustapha, S. K., Antioxidant study of pulp and peel dragon fruits: a comparative study, Int. Food Res., 17, 365-375, 2010.

[30] Rizal, M., Prospek Pengembangan Buah Naga (Hylocereus costaricensis) di Kabupaten Kutai Kartanegara, Kalimantan Timur, Balai Pengkajian Teknologi Pertanian (BPTP) Kalimantan Timur, 884-888, 2015

[31] Robins., Buku Ajar Patologi, Eisi 7, Jakarta,, Indonesia, Penerbit Buku Kedokteran EGC, 2007.

[32] Salamah, S., Sulistiawati, E., Aktawan, A., "Pelatihan Teknologi Kimia Terapan Pembuatan Sabun Cair Cuci Piring, Sabun Mandi Herbal dan Tepung Ampas Kelapa Ibu-ibu Aisyiyah Ranting Perumnas COndong Catur, Depok, Sleman", Jurnal Pemberdayaan, 1(1), pp.470, 2017.

[33] Sari, T. I., Herdiana, E., Amelia, T., "Pembuatan VCO dengan Metode Enzimatis dan Konversinya Menjadi Sabun Padat Transparan", Jurnal Teknik Kimia, 17(1), pp.50-58, 2010. 
[34] Sayuti, K., Yenrina, R., Antioksidan Alami dan Sinteti, edisi 1, Andalas University Press, Padang, 2015.

[35] Shahidi, F., Natural Antioxidants: Chemistry, Health Effects, and Applications. Newfoundland, AOCS Press, 1997.

[36] Spitz, L., Soap Manufacturing Technology, Elsevier Inc, London, 2016.

[37] Sukawaty, Y., Husul, W., Artha, A. V., Formulasi Sediaan Sabun Mandi Padat Ekstrak Etanol Umbi Bawang Tiwai (Eleutherie bulbosa (Mill.) Urb.), Media Farmasi, 13, 14-22, 2016.

[38] Sukeksi, L., Sianturi, M., Setiawan, L., "Pembuatan Sabun Transparan Berbasis Minyak Kelapa dengan Penambahan Ekstrak Buah Mengkudu (Morinda citrifolia) Sebagai Bahan Antioksidan", Jurnal Teknik Kimia USU 2 (7), pp.33-39, 2018.

[39] Sulastri, L., Rizikiyan, Y., "Formulations Transparent Soap Solid Lime Juice (Citrus aurantifolia Swingle)", Jurnal Formulasi Sabun Padat Transparan, 1(1), pp.8-16, 2016.

[40] Widyasanti, A., Farddani, C. L., Rohdiana, D. Pembuatan Sabun Padat Transparan Menggunakan Minyak Kelapa Sawit (Palm Oil) dengan Penambahan Bahan Aktif Ekstrak Teh Putih (Camellia sinensis)", Jurnal Teknik Pertanian Lampung, 5(1), pp.125-136, 2016.

[41] Widyasanti, A., Nugraha, D., Rohdiana, D., "Pembuatan Sabun Padat Transparan Berbasis Bahan Minyak Jarak (Castor Oil) Dengan Penambahan Bahan Aktif Ekstrak Teh Putih (Camellia sinensis)", Jurnal IImu-IImu Pertanian, 1, 2017, 2017.

[42] Wijana, S., Pranowo, D., Taslimah, M. Y. "Penggandaan Skala Produksi Sabun Cair dari Daur Ulang Minyak Goreng Bekas", Jurnal Teknologi Pertanian, 11(1), pp.114-122, 2010.

[43] Zulhipri, Boer, Y., Dyaningtyas, R. P., "Kandungan Fltokimia dan Uji Aktivitas Antioksidan Ekstrak Metanol Kulit Rambutan (Nephelium lappaceum L.) Varietas Binjai dan Lebak Bulus", JRSKT, 2, pp.156-161, 2012 